\title{
The disappearance of public paths in Spain and its impact on landscape justice
}

\section{Miguel Torres García, Michela Ghislanzoni \& Manuel Trujillo Carmona}

To cite this article: Miguel Torres García , Michela Ghislanzoni \& Manuel Trujillo Carmona (2020) The disappearance of public paths in Spain and its impact on landscape justice, Landscape Research, 45:5, 615-626, DOI: 10.1080/01426397.2020.1736532

To link to this article: https://doi.org/10.1080/01426397.2020.1736532

\section{Published online: 16 Mar 2020.}

Submit your article to this journal $\sqsubset$

Џ Article views: 127

Q View related articles $\asymp$

View Crossmark data $\complement \pi$ 


\title{
The disappearance of public paths in Spain and its impact on landscape justice
}

\author{
Miguel Torres García (DD) ${ }^{a}$ Michela Ghislanzoni (D) and Manuel Trujillo Carmona ${ }^{\mathrm{b}, \mathrm{c}}$ \\ ${ }^{a}$ Territoria, análisis y gestión del medio, s.l., Seville, Spain; ${ }^{b}$ Instituto De Estudios Sociales Avanzados (CSIC); \\ cPlataforma Ibérica Por Los Caminos Públicos
}

\begin{abstract}
The public paths network in Spain constitutes state property in the public domain which is endangered by disappearance or misappropriation. This exploratory article asks how this situation has an impact on the right to the landscape. We provide an overview of the situation of public paths in Spain, as well as examples from six case studies, which reveals that much conflict stems from changes in their use and the practices related to them. Public pathways play a key role in the perception of the territory, and their disappearance entails landscape injustices which we need to distinguish from landscapes of injustice.
\end{abstract}

\section{KEYWORDS}

Drove ways; public domain; landscape justice; heritage; rural development

\section{Introduction}

The public paths network in Spain is estimated to extend over more than a million kilometres. In addition, drove roads add up to a total of $125,000 \mathrm{~km}$, of which $32 \%$ is estimated to have been lost, a figure believed to be higher for other categories of pathways. This heritage constitutes state property in the public domain, and as such is inalienable, unseizable and imprescriptible. Public paths nevertheless often disappear, or are misappropriated or squatted, which is denounced by different social actors.

This article aims to use Spanish examples to enrich the debate on landscape and justice, as well as to elucidate how such situations have an impact on the right to the landscape, and to illustrate the manner in which inequities can occur. It also explores the nature of landscape justice beyond revealing social and environmental injustice (Hernández-Morcillo et al., 2017; Jorgensen, 2016, p. 4). To this end, we use the definition of landscape that the Council of Europe puts forward in the European Landscape Convention which, since 2000, has advanced a consensus on the nature of landscape and its relationship with the people.

In the following sections, we briefly explain our approach to this study. We outline how paths can have a bearing on landscape justice, focusing on the perception of the territory. Then we explore the key processes leading to conflict and to the disappearance of public paths, in order to provide a context based on the overarching importance of use, above all other considerations, for their continued existence. We then draw on our case studies to give examples of how different perceptions can become excluded from the landscape as a result of the disappearance of public pathways. After this preliminary approach, we are in a position to situate public paths in relation to the provision of rights to the landscape to the people, and to provide arguments for those who defend them. 


\section{Pathways and the right to landscape}

The European Landscape Convention (hereafter ELC) defines landscape as 'an area, as perceived by people, whose character is the result of the action and interaction of natural and/or human factors' (Council of Europe, 2000). This basic definition provides a common framework for different understandings of the landscape, and establishes a relation between territory and society from which to articulate ideas with regard to the right to the landscape. In this sense, the ELC acknowledges 'that the landscape is a key element of individual and social well-being and that its protection, management and planning entail rights and responsibilities for everyone'. As long as rights are recognised, their denial creates a situation of injustice.

An overarching question rising from the definition is who these people are who perceive, use, shape, and ultimately own it (K. R. Olwig, 2009). For Jones (2007, p. 615), the ELC implies that the views of all groups are to be considered. Further, the Council of Europe establishes that the landscapes, whether outstanding, quotidian or degraded, constitute a commons (Council of Europe, 2000,2008 ), with a bearing on terms of production, rights, duties and benefits (S. Egoz, 2016). It follows that excluding any part of the citizenry from a landscape creates a situation of disadvantage (Barber, 2013; Stobbelaar \& Pedroli, 2011).

As a result, there is a need to reconcile private rights to land and the communal nature of the landscape (D. Mitchell, 2016, p. xxii), which becomes more pressing when the exercise of such rights means the exclusion of people who contributed historically to its very creation. The historical dimension of landscape is also protected by the ELC, for which 'landscape reading also makes it possible to understand current and historical approaches to landscape production as an expression of a community's identity' (Council of Europe, 2008, para. II.2.3.D). In this sense, critical geographers have regarded the landscape as a product of, and in turn as revealing, social and production relationships (cf. D. Harvey, 1996; Mitchell, 2003; K. R. Olwig \& Mitchell, 2009). K. R. Olwig (1996) pays special attention to the origins of the landscape as a spatial expression of customary law and its conflicts with supervened statutory law as a result of the rise of nation states. In subsequent work, K. R. Olwig (2002) continues to conceptualise landscape as part of the body politic, something Mitchell (2003) puts in a context of dialectical struggle.

This approach is not unproblematic when the reciprocities between customs and statutory law over slowly changing social paradigms are complex, and it is sometimes difficult to interpret which prevails, and which is considered fair. In England and Wales, for instance, the 2000 Countryside and Rights of Way Act (CRWA) represents the conciliation, in the form of statutory law, of customary practice, the interests of landholders and the claims of civil associations over several decades (Mayfield, 2010). Such claims stem from an evolving conception of landscape during the 20th century and from historical idiosyncrasies in the land property system. For the same reason, some of the CRWA advances would have little acceptance in the United States, where a modern concept of private property played a foundational role in the current shape and distribution of public and private property, avoiding the long history of conflict which characterises Europe, and where jurisprudence has upheld the understanding of private property as inherently exclusive (Anderson, 2007).

Historical and cultural differences in different territories challenge the understanding of the interpretive dimension of the landscape as just an ideological construction which is subordinated to property and exploitation models (Mitchell, p. 789). Granted, access to the land and its resources is a matter of social and economic justice, but territory is not landscape unless it is subject to sensorial and emotional (Council of Europe, 2008, para. I.2) perception. In recent work, K. R. Olwig (2016) acknowledges the key role of perception in considering equity. He insists on landscape being produced as a place of habitus, but presents the conflict between statutory and customary laws as a matter of the exclusion of other landscapes. He concludes that 'the right right to the landscape is [...] the right to a diversity of landscapes' (p. 48). Therefore, the issue of landscape justice must also be considered as having a more mercurial nature: of being a question of fairness in perception. 
The main provisions made by the ELC with regards to perception come in the shape of a responsibility, placed on the signatory states, to facilitate landscape literacy and to establish procedures for the participation of the public in the broadest sense. That raises the additional problem of accounting for the heterogeneity of landscapes (Jones, 2007, p. 618). The CRWA has been criticised not as much for being the result of mediation between the interests of specific groups, as for the additional restrictions it places, at a performative level, on the use of public rights of way compared to the National Parks and Access to the Countryside Act of 1949 and The Countryside Act of 1968. This is interpreted by Parker and Ravenscroft (2001) as a loss of the possibility of diverse behaviours in public paths. The CRWA also establishes a deadline in 2026 for claiming public rights of way. Those that are not recorded by then will disappear, even if unexpected interests develop in the future which could have use for them.

The importance of these alternative behaviours to the 'diversity of landscapes' to which Olwig refers resides in the idea that pathways mediate between performance, perception and narrativebuilding, and ultimately intervene in their production (Tilley, 1994). Tilley's phenomenology characterises the landscape as relational and dependent on paths (cf. Huijbens \& Benediktsson, 2015, p. 103 on Pallang). T. Ingold's (1993) definition of landscapes as 'the world as it is known to those who dwell therein, who inhabit its places and journey along the paths connecting them' (p. 156) resonates in the ELC as well as recognising the structural role played by paths. Moreover, travelling along a pathway is an act of immersion which involves sensations, where bodily movements bind to feelings, memories, ideas and attachments (e.g. Relph, 1976; Swanwick et al., 2002; Tuan, 1971). For Gibson (in T. Ingold, 2015), perception is not gained through a collection of fixed points, but proceeds along a path of observation.

Pathways, as a means for the vital exploration of the territory, are a medium of, and also shape, perception (cf Huijbens \& Benediktsson, 2015; Molero López-Barajas, 2013). When they are public, rights of way are a vessel for the involvement of the greater public in these processes, and therefore their protection supports the principle of democratisation that the ELC upholds, beyond and prior to the establishment of formal procedures for public participation.

\section{The study}

Our study took an early exploratory turn in view of the scarcity of previous scholarship on the relation between public paths and landscape justice. Adopting a grounded theory approach (Abu-Lughod, 2011; Corbin \& Strauss, 1990), we hypothesised that inequity may happen when the disappearance of a path excludes certain people from the landscape, involves detriment to the living conditions of other species, or compromises the right to the landscape of future generations. In order to provide relevant instances, we issued an open call among users and stakeholders and drew on data held by the Plataforma Ibérica por los Caminos Públicos (PICP). This organisation has been encompassing and coordinating various associations in defence of the environment and public rights of access since 2007. For the open call, we distributed a one-page downloadable questionnaire which considered as parameters the type of pathway, the circumstances under which it is in the process of disappearing, and how injustice is construed by the informant along the lines hypothesised above. The questionnaire was distributed through the PICP's communication channels and other media and social networks: a dedicated website, corporate Facebook profiles, and direct emailing when there was a previously established trust relationship with the recipient. The methods used for gathering the case study suggestions do not account for bias, firstly because the contentious nature of the public paths makes it unrealistic to expect suggestions from other relevant stakeholders such as landowners or administrations-which was confirmed during the detailed case studies-and secondly because we aimed to provide the widest possible variety of circumstances, and considered their precise characterisation as constituting a second research phase.

Over two months we received a total of sixty-eight case study suggestions, from which six were selected following qualitative criteria. After a preliminary analysis, we grouped all the cases according to 
seven types of path, six circumstances of their disappearance, and three overarching types of perceived injustice. Then, we chose a purposive sample (Teddlie \& Yu, 2007) of eight that, on the basis of the information in our hands at the time, were representative, proportional and diverse with regard to the whole. In a subsequent phase of detailed characterisation, two case studies were discontinued because we learnt that they were originally reported incorrectly; in addition, they did not add characteristics unrepresented in the rest of the sample. For each case study, we conducted interviews with our collaborators (see Annex 1, Table 1) or received additional information by email and telephone (see Annex 1, Table 2), and undertook on-site visits, literature reviews and landscape characterisation. We interviewed other users and stakeholders (also in Annex 1, Table 1), a number of whom would not speak on the record. We sought additional context in interviews with experts in the technical and legal (Dr. Xavier Campillo Besses), environmental (Dr. Elisa Oteros Rozas) and heritage (Emilio Molero LópezBarajas) dimensions of public paths (see Annex 1 Table 1). During the data gathering, we obtained material for dissemination which sufficed to produce three online videos, a 44-page leaflet available both in print and online, and a three-poster travelling exhibition which remains at the disposal of the PICP.

\section{Landscapes of injustice vs. landscape injustice}

Our concern in this article is to establish and illustrate whether path disappearance creates a situation of landscape injustice in a wider sense; that is, whether it leads to the exclusion from the landscape qua the perceived territory of those who have a right to it.

Thus, we draw a difference between landscape injustice and landscapes of injustice, in that the latter are the outcome of, and may reveal, inequities, whereas the former cloaks them under an exclusive discourse which naturalises them and makes them seem inevitable, which leads to injustice or struggle (e.g. Setten \& Brown, 2013, p. 244).

Unequal access to the benefits of nature, wealth and the means of production, or to attaining appropriate representation in the management of the land (cf. Dalglish et al., 2018; Jorgensen, 2016), would arguably engender landscapes of injustice (cf. instances from S. Egoz \& Nardi, 2017). There are evident justice issues in the enclosure of public pathways: access to the Spanish territory is granted by the Spanish Constitution (art. 19), so it follows that excluding any citizen from the use of public paths is a violation of their legal rights. But this does not constitute landscape injustice by excluding the public from the land, but because it precludes them from perceiving it.

An instance of landscape injustice, on the other hand, occurs when a group of people are deprived of 'landscape literacy' in Spirn's (2009) terms, or a 'situated' understanding (Waterman, 2018), which would facilitate despotic manipulation and (landscapes of) injustice enduring, undetected. Narratives of landscape often figure in the creation of national or group identities (Olwig, 1996, 2002); the possibility to formulate diverse narratives that can challenge dominant rhetoric (Kolodney \& Kallus, 2016) renders it possible to articulate fairer claims to the territory. Insofar as paths intervene in perception as part of the relational ensemble that, along with narratives and movements, 'produce' landscapes (Tilley, 1994), they have a bearing on landscape justice.

Our case study in Ronda, Malaga, focuses on over ten paths which were closed after a court sentence invalidated the municipal inventory due to formal flaws. Although the verdict did not decide whether they are public or private, the paths remain closed while the commune resumes the research process with the help of civil associations.

This particular case illustrates the role that paths play in the shaping of landscapes. A resident's testimonies do not focus on the Ronda landscape's renowned scenic values as much as on his personal memories and the ways in which the pathways allowed him to interact with his milieu and to reproduce this specific landscape as part of his everyday life:

These paths have always been open. I was raised here, I enjoyed my Ronda and my landscape, and now there is no way to use these paths, to see the river or go for a swim, not even to take a walk. (J. M. Guerrero Sánchez, interview) 
But this case also shows how paths and landscape shape the culture and understanding of landscapes themselves. Ronda is a major example of Andalusian mountain landscapes. Perched over a cliff, surrounded by a mountain skyline and overseeing a small bowl-shaped depression chequered with orchards and watermills, it captivated the fancy of 19th-century romanticist travellers (Fernández Sinde, 2017; Ortega Cantero, 1990, 1999). It made an impression on Rainer Maria Rilke, whose poetry, much discussed in Heidegger's work, has had an impact on the phenomenological approach to the landscape that we discuss here. During his time in Ronda, it is known that the author took long walks along some of the paths surrounding the town (Bermúdez Cañete, 2007) that are now closed.

\section{The status of Spanish public paths and how they disappear: a matter of use}

It is, at this point, worthwhile pointing out that:

The [Spanish] legal framework is [...] very favourable and very protective of public use and public pathways [...] The flaw is in the political commitment and technical defence. (X. Campillo Besses, interview)

Currently, no specific national law regulates public paths, with the singular exception of drove ways, due to their particular historical relevance in Spain. By virtue of the roads law, paths are implicitly defined as all transit routes other than those dedicated to motor traffic. They are known by different names depending on whether they were originally or traditionally used for travelling by foot, on horseback or by cart. Parish roads connect towns and settlements, and towing paths flank water courses for mules to haul freight barges. Drove roads are classified as cañadas, cordeles and veredas according to their width and importance. Farm tracks and forest roads were laid for resource exploitation (Lopez-Monné, 2006).

Unlike in the UK, their typological characteristics are nevertheless, to all practical effects, inconsequential. They are public domain, which is public property intended for general use or public service (Law 33/2003 art. 5 par. 1) — transit in this case. As such, they can never be sold, relinquished or alienated (Law 33/2003 art.6 par. a). In the absence of a dedicated law, they are governed by the lower-ranking consuetudinary law and general principles of the law. The municipalities are responsible for their inventory and maintenance-this is an administrative matter and a considerable load for small communes. If they fail at these tasks, a pathway may materially disappear but, unlike England and Wales under the CRWA, the rights of way never expire.

In the absence of precise data, Trujillo Carmona (2016) estimates that Spain's public paths extend over a million kilometres. In addition, drove roads amount to a total of $125,000 \mathrm{~km}$ and 422,000 ha (Merino García \& Alier Gándaras, 2004), of which 32\% are estimated to be lost (Villalvila Asenjo, 2005 in Trujillo Carmona, 2016). As to the other public paths, Trujillo Carmona (2016) believes that losses in disadvantaged regions could total $70 \%$. The issue of use reappears in the three main processes by which paths can become lost (X. Campillo Besses, interview). In depopulated or mountainous regions, lack of use causes maintenance to be discontinued and the path to deteriorate. Moreover, changes in exploitation methods can render obsolete paths which become abandoned or appropriated by the surrounding estates. Finally, the arrival of foreign sensitivities in rural areas entails changes in management which have an impact on the preservation of paths.

This is the case with the concentration of land into large estates. Urbanites' increasing demand for leisure space can also disrupt large and small holdings, and landowners may feel impelled to close paths in response. Urban settlements also put pressure on neighbouring rural land, causing multiple cases of the occupation of the public domain by infrastructure or urban growth (Trujillo Carmona, 2016). Not only can new owners and users carry an understanding of the landscape which is at odds with the workings of the rural realm, but the technicians, lawyers, politicians and public servants involved in the management and defence of public paths often have an urban mindset.

In summary, the disappearance of public paths is often related to changes in rural practices and administrative shortcomings. Although the Spanish statutory law is very protective of public rights of 
way, it is also very loose regarding their use, which results very much from custom. Customs are in turn rapidly evolving along with living standards, urbanisation, and rural and farming practices.

One of our case studies in Guadalcanal, Seville, illustrates how paths disappear when use wanes. At the meeting point of the Andalusian northern sierras and the southern fields of Extremadura, the hermitage of the Virgin of Guaditoca marked the location of an important three-day-long cattle market which gathered people from Azuaga, Guadalcanal and Reina until the late 18th century (Gálvez Pérez, 2003). The sheer scale of the chapel testifies to the former relevance of this ford and crossroads of trade and cattle routes. The yearly pilgrimage to the shrine is maintained, frequented mostly by the residents of Guadalcanal after the religious fraternities in other towns gradually disappeared. As a result, access from Guadalcanal remains clear, sustained by the annual practice, while the connections to Azuaga are interrupted by a large estate. These two communes are at different stages in the process of inventorying their paths. There is no stipulated process for municipalities to follow when conducting research, and coordination is often an issue (X. Campillo Besses, interview). Consequently, there is currently no official certification as to the paths involved in our case study being public or private. Users from Azuaga are forced to use a combination of other paths and motor roads to reach the hermitage, thus losing the opportunity to re-interpret and give continuity to the 'situated understanding' of an age-old landscape resulting from an idiosyncratic history.

\section{The disappearance of public paths and the exclusion of perceptions}

\section{Old landscapes of latifundia and the eviction of perceptions}

Path enclosure happens more often in the Spanish regions where latifundia have a historical presence, insofar as a particular understanding of property rights persists (X. Campillo Besses, interview), whilst the arrival of new owners with limited knowledge of the local mores and social dynamics creates additional conflicts. This is a recurrent profile in our case studies, in spite of the sample's relatively small size.

This is the case in Otíñar, in Jaén, a valley rich in resources that connects the Andalusian inland sierras and the coast of Granada. Human settlement dates back to the Neolithic Age. Here, a seigniorial territorial model (López Arandia, 2001) survived until the Spanish Civil War (1936-1939), when the tenants attempted to collectivise the land when the landowners momentarily fled. After the insurgents' victory, a decade of reprisals ended in the residents being displaced. The pathways were nevertheless not closed until recently, following a change in ownership.

Perhaps more noteworthy is the case of La Garganta in Ciudad Real. This 15,000 ha consolidated estate is among the largest private hunting grounds in Europe. For years, it has been the target of protests by environmentalist organisations and the PICP, who have denounced on several occasions anti-ecological practices and the closure of public paths. The last occupant, the Duke of Westminster, Gerald Cavendish Grosvenor-recently deceased-, used to give economic support to the festivals in the nearby towns. He also funded six annual grants for local children to improve their English in the United Kingdom, paid for the maintenance of certain pathways and hired tens of neighbours to work on his estate (Muñoz-Lacuna, 2016). His philanthropy contrasts with recurring accounts of harassment from the estate's guards, even in the media (De la Mano, 2014; Ortín, 2016; Villar, 2014).

These two cases pose interesting arguments both supporting and adding nuance to the current literature on landscape justice. Chevalier considers latifundism to be a hierarchic psycho-social framework in which relations of 'protection and oppression' entwine, and which is merely compatible-not consubstantial—with capitalism (Caro Baroja 1963 cit. in Chevalier, 1991, p. 13). Indeed, the latifundia date back to the Roman era and have been renewed throughout history under the feudal, seigniorial, caciquismo, and current capitalist social models. They are part of the historical dispossession processes embedded in the current economic model (cf. D. Harvey, 2003), and 
challenge the legal differences between customary and statutory laws, showing how the latter can be accommodating to the former.

Tensions rose in Otínar during the first decades of the 20th century, as a result of the arrival of new perceptions regarding class and land as means of production. The reprisal and exclusion of the tenants affected perceptions in two ways: First, they expelled challenging interpretations of the landscape as soon as they could be formulated. Second, a depopulated landscape facilitated the recent closing of the old, underused pathways and ultimately prevented other interpretations from being created. The NGO Plataforma por Otiñar y su Entorno was born with an objective to reverse this process and reclaim those other landscapes. Activist defence of public paths was a determining factor in the recovery of alternative interpretations and the eventual listing of Otínar's heritage values: 'The defence of the pathways was the ram which allowed us to get the people back into the Heritage Area' (J. C. Roldán Martín, interview).

In the case of La Garganta, recreation is the main purpose of the estate. It caters to national and international elites who seek privacy and for whom an exclusive landscape is produced. Paternalism continues to be an important part of the property's management strategy, and even if it is beyond the scope of this article to confirm the accounts of harassment in this and other cases we have studied, it becomes clear (Muñoz-Lacuna, 2016) that the property enjoys adamant, and possibly overreaching, support from a section of the local population who wish to preserve their endangered lifestyles. In this sense, it would seem that local customary practice perpetuates inequity, as opposed to the law, which grants universal access to public paths.

\section{New sensitivities towards landscapes: changes in pathways and the continuity of perceptions}

We were alerted to most of our case studies by environmentalists or recreational users of the paths. Public paths are a resource for activities which represent an opportunity for business, the diversification of rural economies and the tourism sector (Cánoves et al., 2004; García Cuesta, 1996). As such, they are objects of dispute between large estates and smaller stakeholders. Beyond economic concerns, the Spanish Constitution specifies that 'everybody has the right to enjoy an adequate environment for their personal development' (art. 45). New standards for this 'personal development' imply novel sensitivities and new experiential paradigms which, propped up by the pathways, produce alternative landscapes over old territories. These new ways of interpreting the land can exclude older ones, or be unwelcome, so devices are interposed in order to reject them.

The Vereda del Salto de la Trocha is a drove way that is also used by pilgrims and tourists who walk the branch of The Way of Saint James heading north from Seville. This Europe-wide route network has become in recent years a sustainable complement to underdeveloped rural economies (Maak, 2009), based on endogenous cultural assets (Ledo et al., 2007). In this section, the original course was substituted at the request of the municipality in 2009 , forcing users to walk $15 \mathrm{~km}$ along the narrow hard shoulder of a local road.

Drove ways cannot be relinquished, but the regional authorities can alter their course, as they did in 2014, provided that there is a proven benefit for the general public (Romero, 2015). In this case, the administrative process was carried out in disregard of more than 500 appeals, and the outcome particularly satisfied the landowners whose property was divided by the original section of the drove way, and who were reportedly impeding access prior to the change (Romero, 2015). The law also stipulates that suitability for cattle transit must be ensured, but the only discernible criterion for the exchange was in regard to the total area commuted: the new section being longer, it is $12 \mathrm{~m}$ wide instead of the distinctive $20.89 \mathrm{~m}$ of a vereda. The file does not discuss whether this change in width affects its capacity for cattle.

The landowners, the politicians and the technicians in the administration used a tool derived from town planning which attended to only the most basic quantitative criteria-surface compensationthus producing a new landscape in both material and perceptual terms (cf. Martin \& Scherr, 2005). In 
doing this, they detracted from the pilgrims' experience, but mostly relegated the herders, despite theirs being the path's primordial age-old use, and for whom the drove roads network constitutes an element of resilience when fuel and fodder prices rise (E. Oteros Rozas, interview). Even though the process followed the law and, in certain terms the result can be construed as being equivalent, it represents the displacement of a whole ensemble of perceptions of this particular landscape. Again, the problem, then, does not strictly reside in the disagreement between customs and statutory law, its spirit being the protection of common use, but rather in the sensitivities and power balances at play in their management.

Another of our case studies provides a more positive note. The Canal de Castilla is a $207 \mathrm{~km}$ water channel transportation network built between the 18th and 19th centuries. It is now used mostly for irrigation after it became obsolete for freight (Sosa Wagner, 2000). The towpaths along its banks are currently open to the public, and some of its ancillary buildings have been retrofitted as attractions for visitors. Through an inter-administrative agreement, the river basin authority and three provincial councils promote recreational activities and tourism and contribute to the conservation of the channel's built heritage. This is an example of how encouraging transit and new uses not only facilitates the preservation of paths, but also updates the cultural values of old landscapes and conveys them to new users. One of our informants, an entrepreneur who organises bicycle tours, describes it as a 'best-selling route' from which other operators in the area also benefit (email correspondence, July 27-28 2017).

\section{Conclusions}

The public pathways provide access to the national territory, which is a right granted by the Spanish Constitution. The mere exclusion of any person from the use of the communal pathways to access the land, its resources, benefits and means of production generates landscapes of injustice. But in actuality these landscapes can reveal underlying inequities, which is a first step to their restitution, as we have shown in the case of Otínar in Jaén. We rather argue, following K. R. Olwig (2016), that as long as landscape is perceived territory, landscape injustice occurs when some perceptions are displaced in favour of others.

The result of the disappearance of pathways is that certain readings are expelled and the landscapes close down to new meanings. In Spain, this is often due to changes in use paired with an abusive or neglectful exercise of power.

Change is part of the landscape, but new sensitivities and uses represent both opportunities for revitalisation and threats of disappearance. The growing interest in nature and active leisure, for which public pathways are a resource, provides additional and alternative uses which contribute to the sustainability of rural areas and landscapes. It can also lead to land concentration for recreational purposes, as we have seen in the case of La Garganta, a large hunting grounds where the social inequities of yesteryear are being reproduced.

We argue that there is no across-the-board opposition of custom and statutory law, as we have detected complex interactions between the two and shortcomings in both of them, as to how to respond to rightful social change. In the case of Spain, where the law is very protective of rights of way but at the same time very reliant on custom, we have seen how the real issue resides in the management of change on the basis of legal, technical and administrative practices. This is the case of the displacement of the Vereda del Salto de la Trocha drove way, and why the Guaditoca hermitage in Guadalcanal risks losing its historical relationships with the territory. In Ronda, administrative shortcomings meant that some residents no longer have access to spaces that are part of their environment and personal memories. As an inspiration, we pose the cases of Otíñar, where the defence of public rights of access has played an important role in the official recognition of an ancestral landscape as a Heritage Area, and of the Canal de Castilla, where new uses and sensitivities have been successfully accommodated, thus giving continuity to its landscape values. 
While in Ronda and Otíñar, civil associations are supporting the municipalities in researching and documenting paths, in the Canal de Castilla, the situation is one of collaboration between administrations. The responsibility for protecting the public domain lies with the latter, but the survival of the public pathways depends on awareness and negotiated use. The ELC gives people the right both to enjoy the landscape and to contribute their regard for it. In order to exercise this, it is essential to reclaim public rights of access.

\section{Acknowledgments}

This work was supported by the Landscape Research Group under the 50th Anniversary Research Fund.

\section{Disclosure Statement}

No potential conflict of interest was reported by the authors.

\section{Funding}

This work was supported by the Landscape Research Group [50th Anniversary Research Fund].

\section{Notes on contributors}

Miguel Torres García is an architect, planner and researcher in the field of urban studies and cultural heritage. He received his DPhil from the University of Manchester in 2015. Prior to that, he studied for an MSc degree in Spatial Planning at Kungliga Tekniska Högskolan, Sweden, and architecture at the Universidad de Sevilla, Spain. His research interests range from the history of architecture and urban spaces to lefebvrean and practice theories, with a particular focus on different frameworks for the analysis of space and place. He has accumulated professional experience in the fields of building design, international aid, and urban and territorial planning. He joined the Spanish consultancy Territoria SLU between March 2015 and December 2019, where he became further acquainted with landscape research and planning.

Michela Ghislanzoni is an architect with twenty years of professional experience. In 2011 she founded Territoria SLU (http://territoria.es), a consultancy for the research, characterization, and planning of landscapes and public open spaces; the protection, planning and enhancement of historical heritage; landscape impact assessment, and the development of tourism products with a territorial focus. He has published her writings on landscape, hiking, historical heritage and landscape impact assessment, and she belongs to networks of experts on spatial planning and landscape and renewable energies. She is an activist in defence of public paths and a member of the Plataforma lbérica por los Caminos Públicos. She has recently organised the course 'Public paths as an environmental resource. Knowing, defending, recovering and enhancing', for the official Andalusian Environmental Training Programme.

Manuel Trujillo Carmona is a technician at the Instituto de Estudios Sociales Avanzados, Consejo Superior de Investigaciones Científicas (CSIC), a sociology research centre dependent on the Spanish state, where he has been responsible for its statistics department since 1997. His main lines of work are the design of surveys and the analysis of small-scale data. In this field, he has been responsible for the design of more than a hundred surveys, as well as other data collection procedures. He is also the coordinator of the Plataforma Ibérica por los Caminos Públicos. This is an umbrella organisation that brings together twenty-nine associations from all over Spain, and has organised thirteen conferences attended by the leading experts on public pathways in the social, legal and administrative fields. Manuel has given more than thirty talks on the circumstances of the closure of public roads and its social consequences.

\section{ORCID}

Miguel Torres García iD http://orcid.org/0000-0002-9904-4649

Michela Ghislanzoni iD http://orcid.org/0000-0001-5591-6065 


\section{References}

Abu-Lughod, J. (2011). Grounded theory. Not abstract words but tools of analysis. In D. R. Judd \& D. W. Simpson (Eds.), The city, revisited: Urban theory from Chicago, Los Angeles, and New York (pp. 21-50). University of Minnesota Press.

Anderson, J. L. (2007). Countryside access and environmental protection: An American view of Britain's right to Roam. Environmental Law Review, 9(4), 241-259. https://doi.org/10.1350/enlr.2007.9.4.241

Barber, L. B. (2013). Making meaning of heritage landscapes: The politics of redevelopment in Halifax, Nova Scotia. The Canadian Geographer/Le Géographe Canadien, 57(1), 90-112. https://doi.org/10.1111/j.1541-0064.2012.00452.x

Bermúdez Cañete, F. (2007). Rilke: Vida y obra. Hiperión.

Cánoves, G., Villarino, M., Priestley, G. K., \& Blanco, A. (2004). Rural tourism in Spain: An analysis of recent evolution. Geoforum, 35(6), 755-769. https://doi.org/10.1016/j.geoforum.2004.03.005

Chevalier, F. (1991). El latifundio en Andalucía y en América. In B. Torres Ramírez (coord.) Andalucía y América. Propiedad de la tierra, latifundios y movimientos campesinos: Actas de las VIII Jornadas de Andalucía y América (Universidad de Santa María de la Rábida 1988), 11-20. Sevilla: Diputación de Huelva

Corbin, J., \& Strauss, A. (1990). Grounded theory research: Procedures, canons, and evaluative criteria. Qualitative Sociology, 13(1), 3. https://doi.org/10.1007/BF00988593

Council of Europe. (2000). European landscape convention. Florence 20/10/2000, ETS № 176, Council of Europe. https:// www.coe.int/en/web/conventions/full-list/-/conventions/treaty/176

Council of Europe. (2008). Recommendation CM/Rec(2008)3 of the Committee of Ministers to member states on the guidelines for the implementation of the European Landscape Convention (adopted by the Committee of Ministers on 6 February 2008), Council of Europe. https://rm.coe.int/16802f80c9.

Dalglish, C., Leslie, A., Brophy, K., \& Macgregor, G. (2018). Justice, development and the land: The social context of Scotland's energy transition. Landscape Research, 43(4), 517-528. https://doi.org/10.1080/01426397.2017.1315386

De la Mano, M. (2014, April 4). Camino Público: Prohibido el paso. El Escarabajo Verde. http://www.rtve.es/television/ 20140404/camino-publico-prohibido-paso/908140.shtml

Egoz, S. (2016). The right to landscape and the argument for the significance of implementation of the European landscape convention. In K. Jorgensen, M. Clemetsen, A.-K. Halvorsen Thoren, \& T. Richardson (Eds.), Mainstreaming landscape through the European landscape convention (pp. 111-118). Routledge.

Egoz, S., \& Nardi, A. D. (2017). Defining landscape justice: The role of landscape in supporting wellbeing of migrants, a literature review. Landscape Research, 42(sup1), S74-S89. https://doi.org/10.1080/01426397.2017.1363880

Fernández Sinde, M. J. (2017). When faraway is mearby: European travellers through Spain. L'Idomeneo, 2016(21), 127-140. https://doi.org/10.1285/i20380313v21p127

Gálvez Pérez, M. S. (2003). De villa a ermita: La pervivencia del hábitat en la Campiña Sur extremeña. Bolskan: Revista De Arqueología Del Instituto De Estudios Altoaragoneses, 20, 191-200. http://revistas.iea.es/index.php/BLK/article/view/ $462 / 459$

García Cuesta, J. L. (1996). El turísmo rural como factor diversificador de rentas en la tradicional economía agraria. Estudios Turísticos, 132, 45-60. http://estadisticas.tourspain.es/img-iet/Revistas/RET-132-1996-pag45-59-77535.pdf

Harvey, D. (1996). Justice, nature and the geography of difference (1 ed.). Blackwell.

Harvey, D. (2003). The New Imperialism. Oxford University Press.

Hernández-Morcillo, M., Bieling, C., Bürgi, M., Lieskovský, J., Palang, H., Printsmann, A., Schulp, C. J. E., Verburg, P. H., Plieninger, T. (2017). Priority questions for the science, policy and practice of cultural landscapes in Europe. Landscape Ecology, 32(11), 2083-2096. https://doi.org/10.1007/s10980-017-0524-9

Huijbens, E., \& Benediktsson, K. (2015). Automobile authorship of landscapes. A biographical vignette of Iceland's interior. In J. Kolen, J. Renes, \& R. Hermans (Eds.), Landscape biographies. Geographical, historical and archaeological perspectives on the production and transmission of landscapes (pp. 99-116). Amsterdam University Press.

Ingold, T. (1993). The temporality of the landscape. World Archaeology, 25(2), 152-174. https://doi.org/10.1080/ 00438243.1993 .9980235

Ingold, T. (2015). The life of lines. Routledge.

Jones, M. (2007). The European landscape convention and the question of public participation. Landscape Research, 32 (5), 613-633. https://doi.org/10.1080/01426390701552753

Jorgensen, A. (2016). Editorial: 2016: Landscape justice in an anniversary year. Landscape Research, 41(1), 1-6. https://doi. org/10.1080/01426397.2016.1115187

Kolodney, Z., \& Kallus, R. (2016). Big and small cityscapes: Two mnemonic landscapes in Haifa, Israel. In S. Egoz, J. Makhzoumi, \& G. Pungetti (Eds.), The right to landscape: Contesting landscape and human rights (pp. 197-210). Routledge.

Ledo, A. P., Bonín, A. R., \& Iglesias, A. M. (2007). El turismo cultural como factor estratégico de desarrollo: El Camino de Santiago. Estudios Geográficos, 68(262), 205-234. https://doi.org/10.3989/egeogr.2007.i262.11

López Arandia, M. A. (2001). De Otiñar a Santa Cristina. Historia de un señorío en la sierra de Jaén. Foro de Papel, 2, $43-72$.

Lopez-Monné, R. (2006, August 2). Los caminos - ¿Qué es un camino? Revista de Senderisme website. http://www. senderisme.com/revfile.aspx?idioma $=$ ca-ES\&idrev $=253 \& i d p r v=218$ 
Maak, K. (2009). El camino de Santiago como posible motor turístico en zonas rurales de escasos recursos: El caso de Brandeburgo. Cuadernos de Turismo, 23, 149-172.

Martin, D. G., \& Scherr, A. (2005). Lawyering landscapes: Lawyers as constituents of landscape. Landscape Research, 30(3), 379-393. https://doi.org/10.1080/01426390500165450

Mayfield, B. (2010). Access to land: Social class, activism and the genealogy of the countryside and rights of way act. Statute Law Review, 31(1), 63-83. https://doi.org/10.1093/slr/hmq005

Merino García, J., \& Alier Gándaras, J. L. (2004). La multifuncionalidad de las vías pecuarias españolas en el marco del desarrollo rural. Tecnología y desarrollo. Revista de Ciencia, Tecnología y Medio Ambiente, 2(Separata), 3-26. https:// revistas.uax.es/index.php/tec_des/article/view/516/472

Mitchell, D. (2003). Cultural landscapes: Just landscapes or landscapes of justice? Progress in Human Geography, 27(6), 787-796. https://doi.org/10.1191/0309132503ph464pr

Mitchell, D. (2016). Foreword. In S. Egoz, J. Makhzoumi, \& G. Pungetti (Eds.), The right to landscape: Contesting landscape and human rights (pp. 21-24). Routledge.

Molero López-Barajas, E. (2013). La memoria de los caminos en el parque natural Sierras de Cazorla, Segura y las Villas. Patrimonio intangible e identidad territorial. Revista Ph, 84, 48-85. https://doi.org/10.33349/2013.84.3410

Muñoz-Lacuna, J. V. (2016, August 11). Ciudad Real también llora la muerte del Duque de Westminster. El Diario Montañés. http://www.eldiariomontanes.es/gente-estilo/201608/11/ciudad-real-tambien-llora-20160811153854-rc. html

Olwig, K. R. (1996). Recovering the substantive nature of landscape. Annals of the Association of American Geographers, 86(4), 630-653. https://doi.org/10.1111/j.1467-8306.1996.tb01770.x

Olwig, K. R. (2002). Landscape, nature, and the body politic: From Britain's Renaissance to America's new world. University of Wisconsin Press.

Olwig, K. R. (2009). Introduction to part one. In K. R. Olwig \& D. Mitchell (Eds.), Justice, power and the political landscape (1 ed., pp. 5-10). Routledge.

Olwig, K. R. (2016). The right rights to the right landscape? In S. Egoz, J. Makhzoumi, \& G. Pungetti (Eds.), The right to landscape: Contesting landscape and human rights (pp. 39-50). Routledge.

Olwig, K. R., \& Mitchell, D. (Eds.). (2009). Justice, power and the political landscape (1st ed.). Routledge.

Ortega Cantero, N. (1990). El paisaje de España en los viajeros románticos. Ería, 22, 121-137.

Ortega Cantero, N. (1999). Romanticismo, paisaje y Geografía. Los relatos de viajes por España en la primera mitad del siglo XIX. Ería, 49, 121-128. https://doi.org/10.17811/er.0.1999.121-128

Ortín, A. (2016). El último gran latifundio español, en la herencia del Duque de Westminster. Vozpópuli. http://www. vozpopuli.com/economia-y-finanzas/empresas/Fincas-Duque_de_Westminster-La_Garganta-Grosvenor_0_ 943105723.html

Parker, G., \& Ravenscroft, N. (2001). Land, rights and the gift: The countryside and rights of way act 2000 and the negotiation of citizenship. Sociologia Ruralis, 41(4), 381-398. https://doi.org/10.1111/1467-9523.00190

Relph, E. (1976). Place and placelessness. Pion.

Romero, J. C. (2015, June 4). Rebelión vecinal contra el cambio de trazado de una vía. ABC, p. 10.

Setten, G., \& Brown, K. M. (2013). Landscape and social justice. In P. Howard, I. H. Thompson, E. Waterton, \& M. Atha (Eds.), The Routledge companion to landscape studies (pp. 243-252). Routledge.

Sosa Wagner, F. (2000). El Canal de Castilla: Alba y aflicción de una obra pública. Revista de Administración Pública, 153, 443-469.

Spirn, A. W. (2009). Restoring mill creek: Landscape literacy, environmental justice and city planning and design. In K. R. Olwig \& D. Mitchell (Eds.), Justice, power and the political landscape (1st ed., pp. 107-125). Routledge.

Stobbelaar, D. J., \& Pedroli, B. (2011). Perspectives on landscape identity: A conceptual challenge. Landscape Research, 36 (3), 321-339. https://doi.org/10.1080/01426397.2011.564860

Swanwick, C.; Countryside Agency, \& Scottish Natural Heritage. (2002). Landscape character assessment: Guidance for England and Scotland. Countryside Agency.

Teddlie, C., \& Yu, F. (2007). Mixed methods sampling: A typology with examples. Journal of Mixed Methods Research, 1(1), 77-100. https://doi.org/10.1177/2345678906292430

Tilley, C. Y. (1994). A phenomenology of landscape: Places, paths and monuments. (B. Kapferer \& J. Gledhill, Eds.). Berg 3PL.

Trujillo Carmona, M. (2016). Situación de las vías pecuarias y los caminos públicos y su defensa ciudadana. Fundación de Estudios Rurales. Anuario, 2016, 164-170.

Tuan, Y.-F. (1971). Geography, phenomenology, and the study of human nature. The Canadian Geographer/Le Géographe Canadien, 15(3), 181-192. https://doi.org/10.1111/j.1541-0064.1971.tb00156.x

Villar, C. (2014, February 11). Así es la finca de Ciudad Real donde caza el príncipe Guillermo. ELMUNDO. http://www. elmundo.es/loc/2014/02/11/52f90f28268e3eab198b458a.html

Waterman, T. (2018). Democracy and trespass: Political dimensions of landscape access. In S. Egoz, K. Jørgensen, \& D. Ruggeri (Eds.), Defining landscape democracy: A path to spatial justice (pp. 143-152). Edward Elgar Publishing. 


\section{Annex 1}

Table A1. Interviews.

\begin{tabular}{|c|c|c|c|}
\hline Name & Capacity & Interview date & Case study/Topic \\
\hline Manuel Rodríguez Espejo & Activist & 17 April 2017 & Vereda del Salto de la Trocha \\
\hline Mercedes Mulero Ramos & Activist & 17 April 2017 & Vereda del Salto de la Trocha \\
\hline Sebastián Carrizosa Molina & President, Azuaga cycling club. & 12 June 2017 & Guadalcanal \\
\hline Raúl Romero Blanco & Municipal ranger & 12 June 2017 & Guadalcanal \\
\hline José M. Guerrero Sánchez & $\begin{array}{l}\text { Activist, Plataforma por los } \\
\text { Caminos Públicos de la Serrranía } \\
\text { de Ronda }\end{array}$ & 22 June 2017 & Ronda \\
\hline David García Hernández & Forestry engineer & 22 June 2017 & Ronda \\
\hline Dr. Elisa Oteros Rozas & $\begin{array}{l}\text { Postdoctoral researcher, } \\
\text { Universidad Pablo de Olavide. }\end{array}$ & 21 July 2017 & Environmental aspects of paths. \\
\hline Dr. Xavier Campillo Besses & Specialist in path inventory & 26 July 2017 & $\begin{array}{l}\text { Technical and legal aspects of } \\
\text { paths. }\end{array}$ \\
\hline J. Carlos Roldán Martín. & Activist & 23 August 2017 & Otíñar \\
\hline Emilio Molero López-Barajas & Author & 23 August 2017 & Otínar/Heritage aspects of paths \\
\hline
\end{tabular}

Table A2. Email communications.

\begin{tabular}{|c|c|c|c|}
\hline Name & Capacity & Interview date & Case study/Topic \\
\hline $\begin{array}{l}\text { Vicente Luchena } \\
\text { - }\end{array}$ & $\begin{array}{l}\text { Ecologistas en Acción Valle de Alcudia } \\
\text { Tour operator }\end{array}$ & $\begin{array}{l}\text { July18th-20 September } 2017 \\
\text { July 27th-28th } 2017\end{array}$ & $\begin{array}{l}\text { La Garganta } \\
\text { Canal de Castilla }\end{array}$ \\
\hline
\end{tabular}

